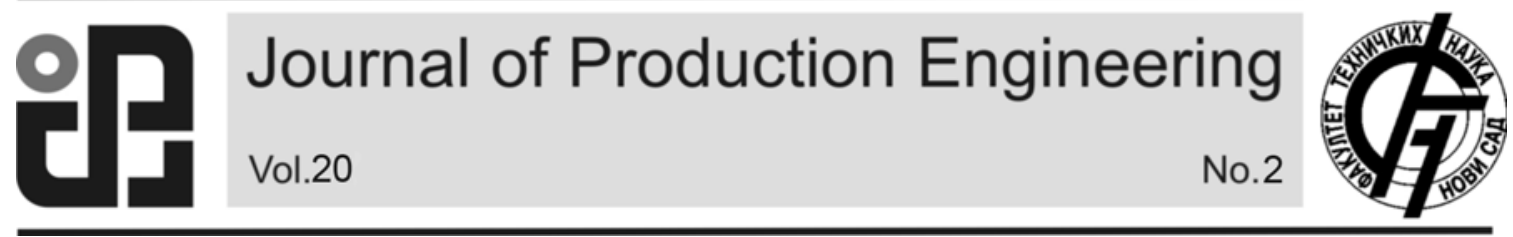

JPE (2017) Vol.20 (2)

Alabi, A.G.F., Aweda, J.O, Aluko, F.I.

Original Scientific Paper

\title{
INFLUENCE OF FERROSILICON MANGANESE ON THE SULPHUR CONTENT AND MICROSTRUCTURE IN THE PRODUCTION OF AUSTEMPERED DUCTILE IRON (ADI)
}

\author{
Received: 22 September 2017 / Accepted: 12 November 2017
}

\begin{abstract}
This study considers the effect of ferrosilicon manganese addition to austempered ductile iron, (ADI) in order to reduce its sulphur level for improved engineering applications of the material. The cast samples were austenitised in a mixture of potassium chloride, sodium chloride and barium chloride solutions and austempered in sodium nitrate and potassium nitrate solutions. Ferrosilicon manganese was added to ADI in various amounts ranging from between 47 to $326 \mathrm{~g}$. The study revealed that the sulphur level retained in ADI decreased from 0.088 wt \% for as-cast to 0.027 wt \% when $93 \mathrm{~g}$ of ferrosilicon manganese was added. Below this amount of ferrosilicon manganese addition, there was no significant reduction in the sulphur level recorded in ADI. The microstructure of the metal revealed bigger graphite nodules scattered in ferrite solutions for the situation when the sulphur level was $0.027 \mathrm{wt}$. \%. From the study, it was discovered that addition of small amount of ferrosilicon manganese was required to produce ADI of low level sulphur content to make the metal more acceptable for other engineering applications.
\end{abstract}

Key words: Ductile iron, sulphur, austempering, nodularizer, ferrosilicon

Uticaj ferosilikonskog mangana na sadržaj sumpora i mikrostrukturu u proizvodnji izotermalno poboljšanog gvožđa (ADI). Ova studija razmatra uticaj dodatka ferozilicijevog mangana na izotermalno poboljšano gvožđe (ADI) kako bi smanjio nivo sumpora u cilju poboljšanja inženjerske primene materijala. Uzorci odlivaka su austenitizovani u mešavini kalijum hlorida, natrijum hlorida $i$ rastvora barijum hlorida $i$ austemperovani $u$ rastvorima natrijum nitrata $i$ kalijum nitrata. Ferosilicijum mangan je dodat u ADI u različitim količinama $u$ rasponu od 47 do $326 \mathrm{~g}$. Studija je utvrdila da je nivo sumpora zadržan u ADI je smanjen sa 0,088 tež.\% za livenje na 0,027 tež.\% kada je dodato $93 \mathrm{~g}$ ferosilikon mangana. Ispod ove količine ferosilicijevog manganskog dodatka, nije bilo značajnog smanjenja nivoa sumpora zabeleženog u ADI-u. Mikrostruktura metala otkrila je veće grafitne nodule raspršene u feritnim rastvorima za situaciju kada je nivo sumpora bio 0,027 tež. \%. Studija je utvrdila da je dodatak male količine ferosilikovanog mangana potreban za proizvodnju ADI sadržaja sumpora na niskom nivou kako bi metal bio prihvatljiviji za druge inženjerske aplikacije.

Ključne reči: Nodularno gvožđe, sumpor, izotermalno poboljšanje, nodularizator, ferosilikon

\section{INTRODUCTION}

Discovering new materials with improved mechanical properties meeting the required applications has engaged the attention of researchers worldwide. In recent years, Austempered Ductile Iron (ADI), obtained from ductile iron, has attracted considerable applications because of its good mechanical properties. Such properties include resistance to fatigue [1-4], good wear resistance [5, 6], high strength with good ductility [7-9] and good rolling contact resistance [10]. The density of ADI is lower than steel $[8,12]$ which makes it more applicable in the areas of production of engine blocks and other engineering components. ADI is used in the production of swivel pins, rail brakes and pressure pipes in the oil industry [13-16]. Thus, ADI has been found to have higher specific strength than steel $[6,17-$ 21]. Austempered ductile iron products are used in the automobile and textile industries as crank shafts, cam shafts, gearwheels and thin wall castings reinforced parts $[10,16,18,26]$. The production of ADI is cheaper when compared with forged steel by $20 \%$ [27, 28]. Compared to steel, ADI exhibits improved properties in terms of machinability, tool life and machining speeds, surface finish, improved safeguard against failure (due to the lubricating effect provided by graphite) [17, 22], good ballistic properties [26], good resistance to bending fatigue [1], good damping capacity (better noise attenuation), amenability to heat treatment $[6,21$, 24, 25], good corrosion resistance [24].

Therefore, ADI is considered as an economical substitute for wrought or forged steel in several structural applications [2, 3]. The metal loses less of its toughness than steel at sub-zero temperature. Austempered ductile iron usually work-hardens when stressed and has good vibration damping capability and heat transfer than other ferrous and non-ferrous alloys $[18,22,26]$.

Liu [26] in his work suggested that an improved structure of ADI could be obtained by controlling the heat treatment process of nodular cast iron. The microstructure and mechanical properties of ADI can be influenced by the isothermal heat treatment and the temperature of austenite transformed [16]. The temperature of isothermal transformation is in the range of 250 and $450{ }^{\circ} \mathrm{C}$ [18]. When higher transformation 
temperature above $450{ }^{0} \mathrm{C}$ is used, it resulted in lower strength and hardness but higher elongation and toughness and better fatigue characteristics [18, 23].

However, substantial amount of sulphur in ADI and other ferrous alloys have negative effect on their mechanical properties hence limiting their applications $[1,17,18]$. Other factors limiting the use of ADI include the low nodule count caused by long holding time in the furnace, prolonged pouring time and low carbon equivalent $[11,26]$ where the precipitating graphite was not adequate during cooling under inoculation or when pouring temperature is high.

In this work, standard method of producing austempered ductile iron was used while adding ferrosilicon manganese in varying quantities to it in the molten state. This was done such that the sulphur content in the produced ADI will be minimized which will consequently enhance the metal's applicability in engineering service.

\section{MATERIALS AND METHOD}

Grey cast iron scraps with percent weight of 0.199 of sulphur and other constituents from automobile engine blocks and graphite were collected and melted. The scraps were broken into smaller sizes to facilitate fast melting in the lift out crucible furnace used which was located in the foundry workshop of the Engineering Materials Development Institute (E.M.D.I), Akure, Nigeria.

\subsection{Method of production}

The production procedure of austempered ductile iron involved the processing of ductile iron casting that was austenized at temperatures between 800 and $950{ }^{\circ} \mathrm{C}$. It was then quenched to a temperature of $250-400{ }^{0} \mathrm{C}$ in salt bath of potassium nitrate and sodium nitrate [17]. The rapid cooling referred to as austempering, was given to avoid the formation of pearlite or other microconstituents to a temperature above martensite start (MS). It is possible to produce both compacted graphite irons and ductile iron from the same base iron by using cored wire containing a high magnesium and ferrosilicon. Magnesium ferrosilicon was used as nodularizer, while ferrosilicon was used as inoculants for the grey cast iron. The nodularizer was poured into the ladle while the inoculants were added in the prepared mould. Ferrosilicon manganese was added to the melt of the grey cast iron scraps in the furnace.

\section{CASTING PROCEDURE}

\subsection{Melting process}

The weights of the graphite, magnesium ferrosilicon and ferrosilicon manganese were measured using OHAUS-CS2000 electronic weighing machine at the foundry workshop of E.M.D.I., Akure. An Avery weighing scale of $250 \mathrm{~kg}$ capacity was employed in measuring the weight of the scraps that were melted in the rotary furnace. The furnace was $100 \mathrm{~kg}$ capacity oil fired designed and constructed locally by E.M.D.I. Akure. Eighteen grams each of powdered graphite and powdered ferrosilicon were introduced into the pocket of the mould before pouring of the molten metal in to the mould for casting. Magnesium, $700 \mathrm{~g}$, and $18 \mathrm{~g}$ of powdered ferrosilicon were added as inoculants for all the melts. Ferrosilicon manganese with quantity ranging from between $47 \mathrm{~g}$ to $326 \mathrm{~g}$ was introduced in to the furnace for different melts. The temperature of the furnace was taken at an interval of ten minutes during melting process to ascertain that the material was completely molten. After the material had become molten, the tap hole of the furnace was opened. The ladle was brought near the furnace and the rotary furnace was tilted to pour the molten metal into the ladle. The ladle was preheated to a temperature slightly above $500^{\circ} \mathrm{C}$ and maintained at this temperature through the period of pouring into the prepared mould. After pouring, the melt was allowed to solidify freely in the mould. All specimens were prepared while varying the amount of ferrosilicon manganese added from $47 \mathrm{~g}$ to $326 \mathrm{~g}$. For the control, the same process was followed except that ferrosilicon manganese was not added in the process of melting.

The scraps used had the sulphur content as 0.199 percent weight and other components that was determined using Optical Emission Spectrometry. Table 1 shows the amount of sulphur in the initial ductile iron and final composition after the addition of varying amounts of ferrosilicon manganese.

\begin{tabular}{cccc}
\hline Melt & $\begin{array}{c}\text { Sulphur } \\
\text { content } \\
\text { in the scrap } \\
\text { (\% wt) }\end{array}$ & $\begin{array}{c}\text { Ferrosilicon } \\
\text { manganese } \\
\text { added } \\
\text { (g) }\end{array}$ & $\begin{array}{c}\text { Final values of } \\
\text { sulphur } \\
\text { retained } \\
\text { (\% wt) }\end{array}$ \\
\hline A & 0.199 & 0 & 0.088 \\
B & 0.199 & 326 & 0.086 \\
C & 0.199 & 233 & 0.030 \\
D & 0.199 & 140 & 0.028 \\
E & 0.199 & 93 & 0.027 \\
F & 0.199 & 47 & 0.027 \\
\hline
\end{tabular}

Table 1 . The initial and the actual values of sulphur contents

\section{RESULTS AND DISCUSSION}

\subsection{Effects of ferrosilicon manganese addition to ADI compositions}

Figure 1 is the graph of various melts with composition of sulphur by weight \% in the melts. With the addition of ferrosilicon manganese in varying amounts, the sulphur weights \% retained were between 0.027 and 0.086 . The highest value was recorded in melt A (0.088), the control and the least value of $0.027 \mathrm{~g}$ in Melts E and F. The sulphur content slightly reduced to 0.086 weight $\%$ for melt B when ferrosilicon manganese of $326 \mathrm{~g}$ was added. For melts $\mathrm{C}$ to $\mathrm{F}$, when the added ferrosilicon manganese was reduced the sulphur content was greatly reduced from 0.030 to 0.027 . There is no much difference between the sulphur weight percent of melts $\mathrm{D}$ to $\mathrm{F}$ as seen from the figure. The reduction in \% weight composition of sulphur might have been through the addition of ferrosilicon manganese in smaller quantity where sulphur had reacted with manganese to form manganese sulphide, a slag that floated on the cast metal during casting. The graph also shows that with a 
little amount of ferrosilicon manganese addition to the ductile iron not exceeding $93 \%$ weight, the sulphur content is significantly reduced.

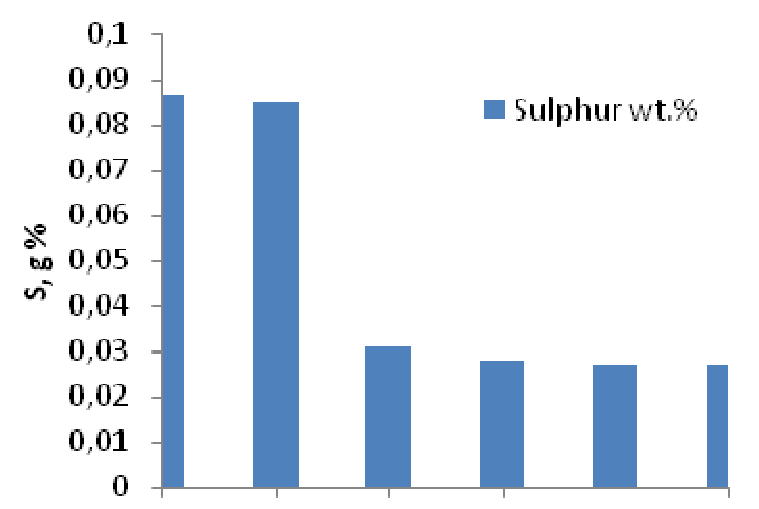

MeltA Melte Meltc Melt D Melte MeltF

Fig. 1. Sulphur content in various melts

Figure 2 presents the composition of silicon percent weight in various melts as the quantity of ferrosilicon manganese added to ADI was varied for different melts. The silicon weight percent increased from Melt B to Melt $\mathrm{E}$ as the amount of ferrosilicon manganese added decreased. When $326 \mathrm{~g}$ of ferrosilicon manganese was added as in Melt B, the silicon retained was $1.87 \mathrm{~g} \% \mathrm{wt}$ this amount increased to $2.95 \mathrm{~g}$ when $93 \mathrm{~g}$ of ferrosilicon manganese was added as represented in Melt E. With the addition of $47 \mathrm{~g}$ of ferrosilicon manganese (Melt $\mathrm{F}$ ), the amount of silicon retained reduced to $2.87 \mathrm{~g} \% \mathrm{wt}$. The amount of silicon deposited was reduced because of the reduced quantity of ferrosilicon manganese that was added which led to less silicon available for the reaction.

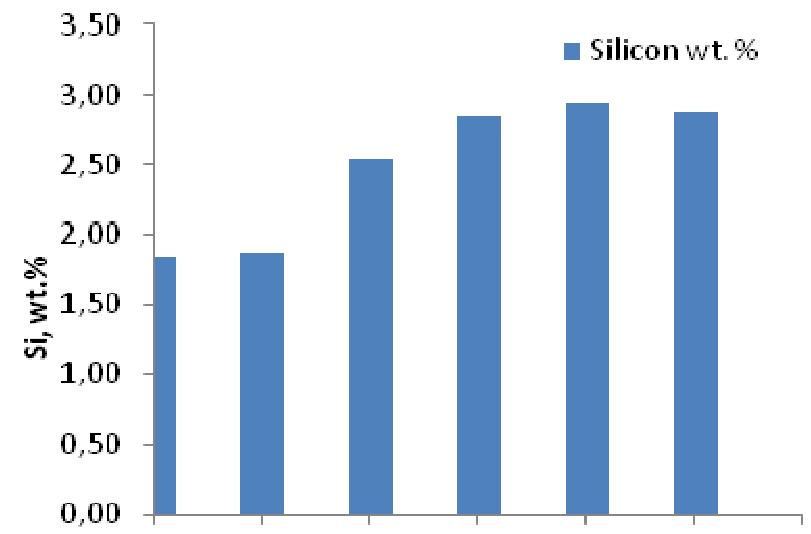

Melt A MElt B Melt C Melt D MeltE MeltF

Fig. 2. Silicon content of vrious melts

From figure 3, the weight \% of magnesium present in the ADI with the addition of ferrosilicon manganese ranged from between $0.0042 \mathrm{~g}$ for Melt A to $0.035 \mathrm{~g}$ for Melt F. Melt A which is the control, has the least weight $\%$ of $0.0042 \mathrm{~g}$, while Melt $\mathrm{F}$ has the highest with 0.035 g. The weight \% of magnesium present in ductile iron is usually not above 0.05 weight $\%$. This amount obtained was likely due to the magnesium been deposited into the cast metal which resulted into the formation of magnesium ferrosilicon.

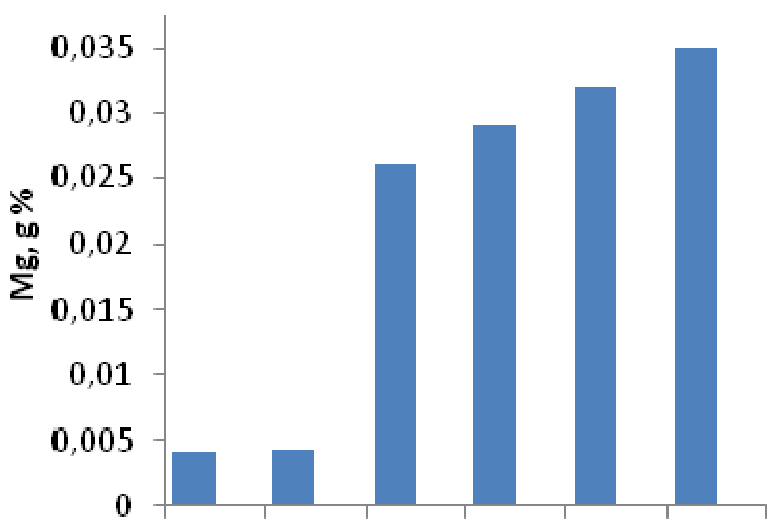

Melt A Melt B. Melt CMelt D MeltE MeltF

Fig. 3. Magnesium contents of various melts

Figure 4 represents the amount of iron retained in the melts with the addition of ferrosilicon manganese. The values of iron present in the melts were between 93.5 and $92.06 \mathrm{~g}$ for Melts A (control) and D respectively. The percentage change in the amount of iron present in the ADI from the control sample when ferrosilicon manganese was not added to that of Melt D when $140 \mathrm{~g}$ of ferrosilicon manganese was added is 1.5 $\%$. This results show that addition of ferrosilicon manganese into ADI has no much influence on the \% wt of iron in the metal.

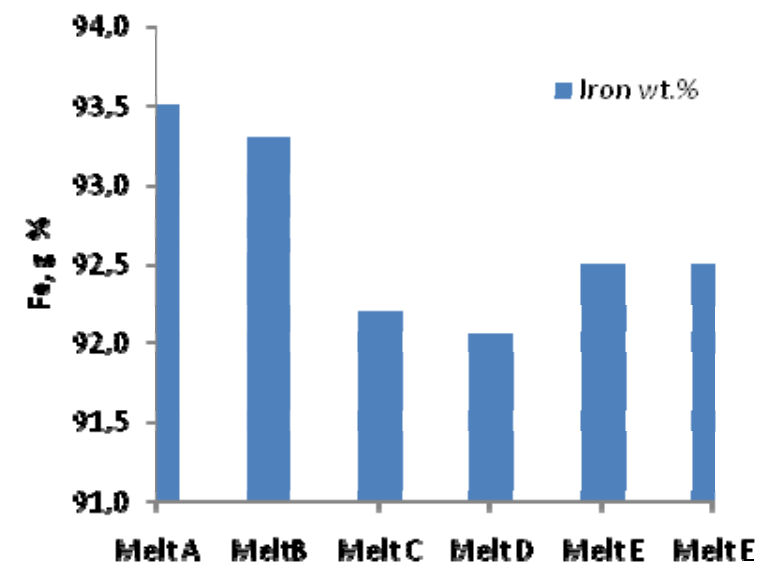

Fig. 4. Iron contents of various melts, wt.\%

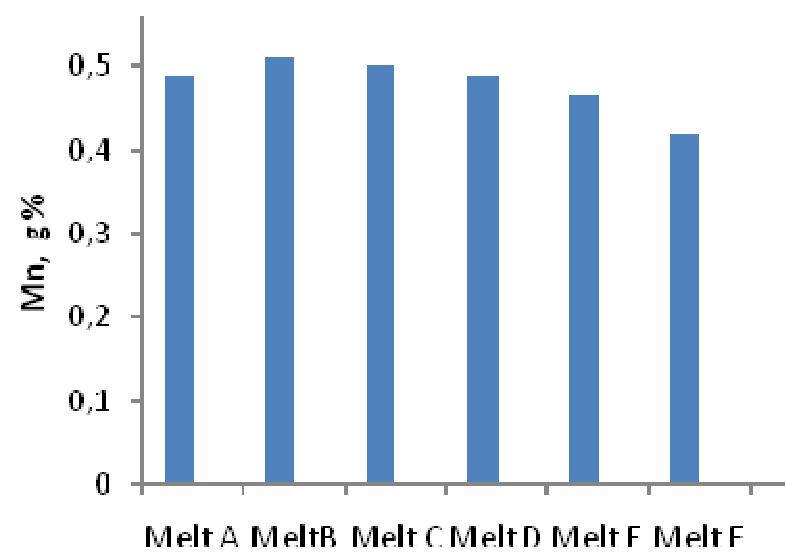

Fig. 5. Manganese contents of various melts, wt. \%

The weight \% of manganese present in the metal decreased from 0.510 to $0.419 \mathrm{~g}$ as shown in figure 5 . 
The amount of manganese retained after the casting was reduced from Melts B to $\mathrm{F}$ as the amount of ferrosilicon manganese added was reduced. Even though no ferrosilicon manganese was added to Melt A, about 0.488 weight $\%$ of manganese was recorded in the cast metal. The reason for the low manganese content in Melts B to F may be ascribed to the reactions that took place within the furnace where manganese and sulphur reacted to form manganese sulphide.

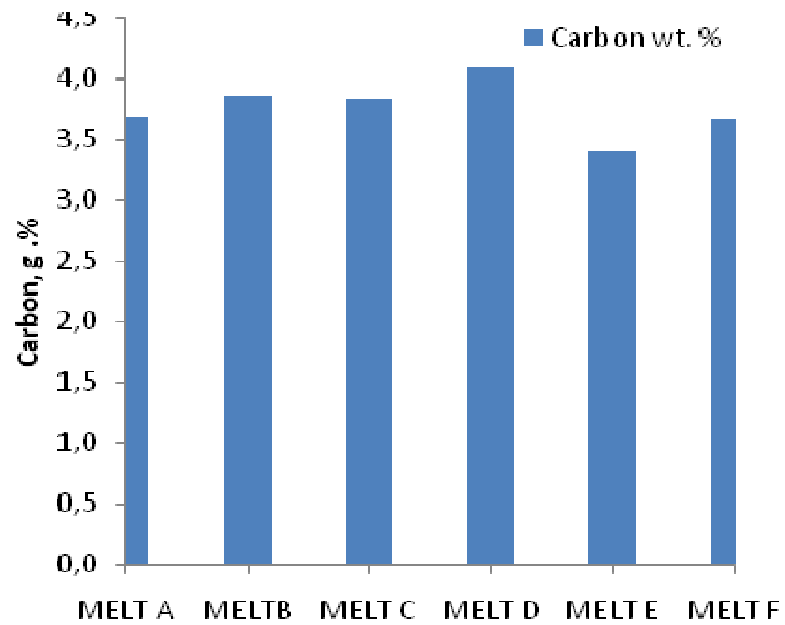

Fig. 6. Carbon contents in various Melts, wt \%

Figure 6 depicts the carbon weight \% of the sample which falls between 3.41 and 4.1 wt. percent with ferrosilicon addition in varying amounts. Melt $\mathrm{D}$ has the highest weight percent of $4.1 \mathrm{~g}$ while Melt E has the least, $3.41 \mathrm{~g}$ as reflected in the figure. Melts B and C have 3.87 and 3.84 weight \% respectively. The control, Melt A grey cast iron has 3.68 weight \%. This lower value may be an indication that some carbon might have reacted with oxygen to form carbon monoxide which would have diffused into the air. Melt D with highest carbon content may likely show improved mechanical properties

\subsection{Effect of ferrosilicon manganese on microstructures}

Figure $7 \mathrm{a}$ is the micrograph of Melt $\mathrm{A}$ when no ferrosilicon manganese was added to ADI. The microstructure revealed long graphite flakes within ferrite which probably is an indication that the metal will be soft and easy to machine.

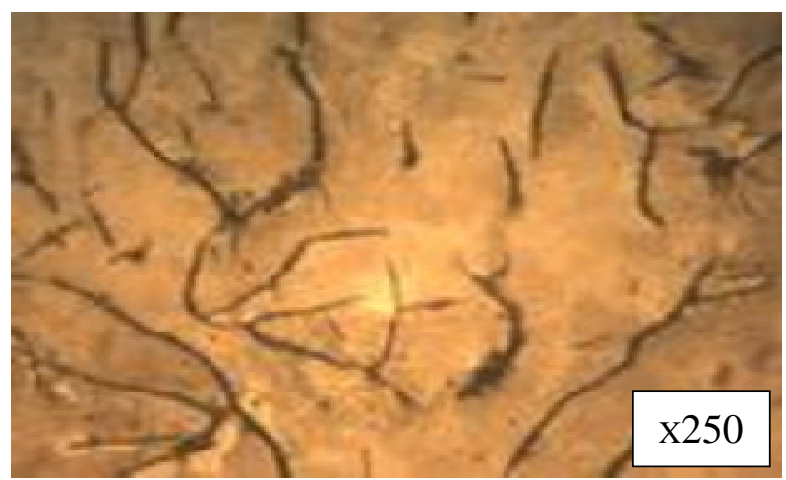

Fig. 7a. Micrograph of Melt A
Figure $7 \mathrm{~b}$ represents the micrograph of the metal with the addition of $326 \mathrm{~g}$ of ferrosilicon manganese where the graphite stripes turned to graphite nodules. The graphite nodules form lumps and are surounded by ferrite within the matrix. The lumped nodules are seen scatered within ferrite. This formation implies that the material is ductile iron. The silicon resulting from the added ferrosilicon has shown its potency for ferrite formation in the ductile iron

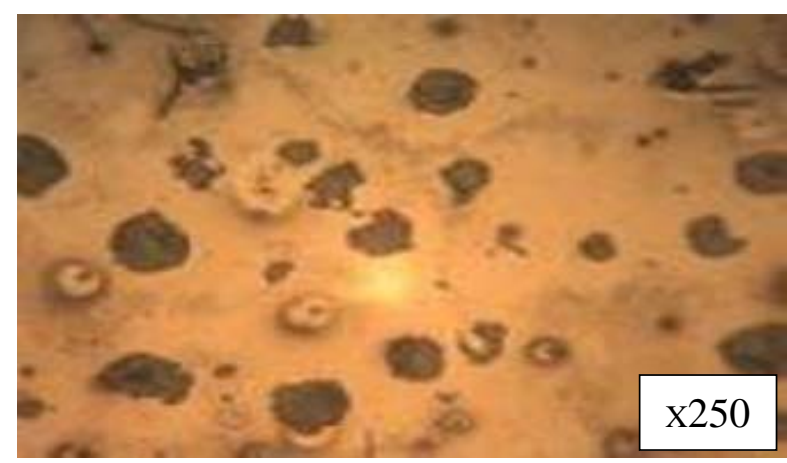

Fig. 7b. Micrograph of Melt B

Figure 7c is the microstructure of Melt D when 140 $\mathrm{g}$ of ferrosilicon manganese was added to ADI. The micrograph shows the presence of high concentration of graphite nodules within ferrites. Figure $7 d$ represents the microgrph of Melt $\mathrm{E}$ when $93 \mathrm{~g}$ of ferrosilicon manganese was added showing bigger graphite nodules than that obtained for Melt D and relatively scattered all over the surface within ferrite confirming the results obtained by Alasoluyi et al;[12]

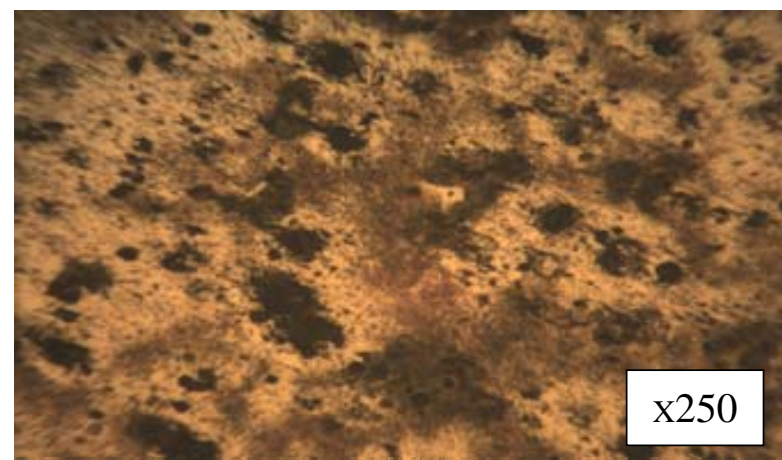

Fig. 7c. Micrograph of Melt D

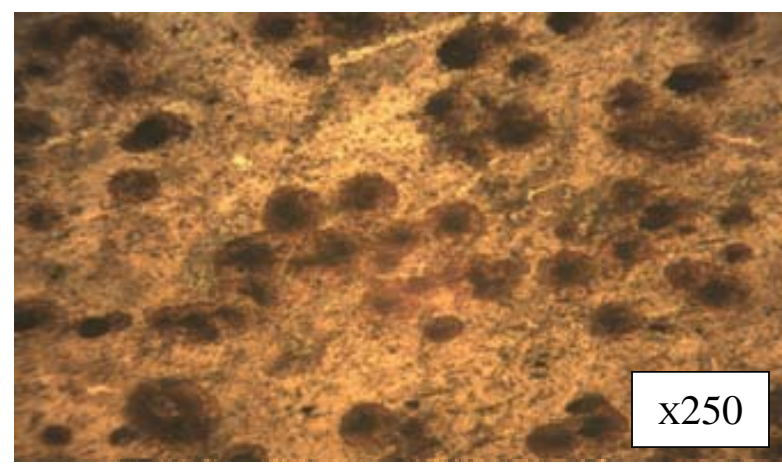

Fig. 7d. Micrograph of Melt E

Figure 7e is the situation when $47 \mathrm{~g}$ of ferrosilicon manganese was added to ADI. The microstructure as shown on the figure contained very few but big graphite 
nodules with ferrites fairly scatered all over the surface. This similar effect was also observed by Alasoluyi et al; [6] in their work. The silicon from the ferrosilicon is seen to initiate the formation of the ferrite and tends to be slightly forming in the pearlite of the matrix. This also promotes the precipitation of the graphite nodules in pearlite matrix with little ferrite in existence. The figure reveals that the presence of ferrite is been usurped by the appearance of pearlite within the metal.

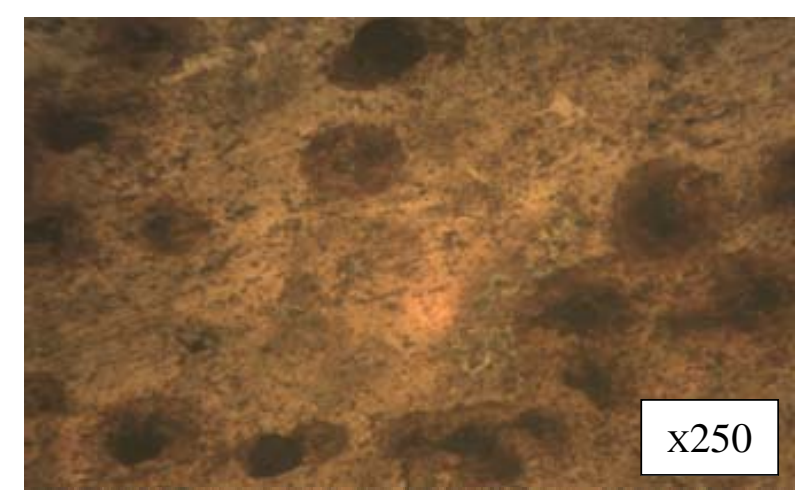

Fig. 7e. Micrograph of Melt F

\section{CONCLUSIONS}

Austempered ductile iron was produced by casting process through the addition of varying amount of ferrosilicon manganese in the ranges of 47, 93, 140, 233, 326 wt. \% using lift out crucible furnace. The compositional analysis and microstructural examinations of the products were evaluated and compared with the as-cast. The following conclusions are made from the study;

1. Austempering of ductile iron in a lift out crucible furnace was successfully carried out.

2. Addition of ferrosilicon manganese to ADI has influence on the amount of sulphur and other constituent elements retained in the metal.

3. Addition of $47 \mathrm{~g} \% \mathrm{wt}$. of ferrosilicon manganese to ADI shows significant lowering of sulphur retained in the metal after casting.

The microstructural examinations revealed that the graphite nodules were well distributed in the ADI

\section{REFERENCES}

[1] Yamanaka, M., Tamura, R., Inoue, K. and Narita, $\mathrm{Y}$.: Bending fatigue strength of austempered ductile iron spur gears, Journal of Advanced Mechanical Design, Systems and Manufacturing, vol. 3(3), (2009), 203-211.

[2] Hassan, S.B.: Austempered Ductile cast Iron-An Alternative to steel and Aluminiums in Automotive Applications, Nigerian Mining Journal, 5(1), (2007), 32-39.

[3] Adewuyi, B.O., Afonja, A.A. and Adegoke, C.O.: Effects of Isothermal Transformation on Fatigue strength of Austempered Ductile Iron, Botswana Journal of Technology, vol. 14 No 2 (2005), 21-25.

[4] Aluko, F.I.: Effect of Heat Treatment on Corrosion Properties of Gray Cast Iron in Paper making industries, Nigerian Journal of Engineering
Management, Besade Publishing press. Ondo, 5(1), (2004), 31-33.

[5] Rebasa, N., Dommarco, R., and Sikora, J.: Wear Resistance of High Nodule Count Ductile Iron, (T8), Hokongghub, ElsevierScience, vol. 253, (2002), 855-861.

[6] Alasoluyi, J.O., Omotoyinbo, J.A., Olusunle, S.O.O. and Adewuyi, O.O.: Investigation of Mechanical Properties of Ductile Iron Produced from Hybrid Innoculants using Rotary Furnace, International Journal of Science and Engineering, vol. 2(5), (2013), 338-393.

[7] Keough, J.R. and Hayrynen, K.L.: Designing with austempering ductile iron (ADI), American Foundry Society, (2010), 1-15.

[8] Hassan, S.B.: The Effect of Chromium Additions on Microstructure and Mechanical Properties of Nodular Cast Iron, N.S.E.Technical Transaction, 41(3), (2006), 33-41.

[9] Behmani, M., Elliot, R. and Varehan, N.: Austempered Ductile Iron: A Competitive Alternative for Forged Induction-Hardened Steel Crankshafts, International Journal of Cast Metals Research, vol. 9, (1997), 249-257.

[10] Nofal, N.: Advances in the metallurgy and applications of ADI, Journal of Metallurgical Engineering (ME), vol. 2(1), (2013), 1-18.

[11] Shiokara, T.: Effect of Graphite Nodules on Crack Growth Behavior of Austempered Ductile Cast Iron (ADI), 59 $9^{\text {th }}$ Japan Ductile Cast Iron. Association Conference, Tokyo, Japan, (1978), 138-150.

[12] Alasoluyi, J.O., Omotoyinbo, J.A., Borode, J.A., Olusunle, S. O.O. and Adewuyi, O.O.: Influence of Secondary Introduction of Carbon and Ferrosilicon on the Microstructure of Rotary Furnace Produced Ductile Iron, International Journal of Science and Engineering, vol. 2(2), (2013), 211-217.

[13] Vechet, S., Kohout, J., Klakurkova, L.: Fatigue Properties of Austempered Ductile Iron in Dependence Transformation Temperature, Material Science (Medziagotyra), 14(4), (2008), 324-327.

[14] Trudel, A. and Gagne, A.: Effect of Composition and Heat Treatment Parameters on the Characteristics of ADI, Canadian Metallurgical, (1998), 289-298.

[15] Hassan, S.B. and Isah, L.A.: A study of relationship between Tensile Properties and Microstructure of low Alloy Austempered Ductile Iron Using Khaya Senegalensis Seed Oil as Quenchant, Journal of Metallurgy and Materials Engineering, 5 (2), (2010), 14-21.

[16] Bhople, N., Pahl, S. Harne, M. and Dhande, S.: Austempering parameters and machinability of austempering ductile iron: A comprehensive review on effective parameters, International Journal of Innovative Research in Science, Engineering and Technology, vol. 5(2), (2016), 1197-1211.

[17] Myszka, M. and Presz, W.: Microstructure transformations in austempered ductile iron during 
deformation by dynamic hardness test, Computer methods in Materials Science, vol. 12(4), (2012), 259-263.

[18] Sikora, J. and Boeri, R.: Advances in ductile iron research: New metallurgical understanding and its Technological Significance, Archives of Foundry, vol. 5(15), (2005), 354-360.

[19] Kaczorowski, M. and Krzynska, A.: Mechanical Properties and Structure of Austempered Ductile Iron-ADI, Archives of Foundry Engineering, Publications of Foundry Commission of the Polish Academy, vol. 7, (2007), 161-166.

[20] Uma, B.: Influence of composition and austempering temperature on machinability of austempered ductile iron, International Journal of chemical, nuclear, Metallurgical and Materials Engineering, 7 (2), (2013), 116-121.

[21] Yawas, D.S.: Corrosion Characteristics of Mild Steel and Ductile Cast Iron Exposed to Different Media, N.S.E. Technical Transaction vol. 41 (3), (2006), 125-134.

[22] Bela, V. and Kovas, Sr.: Autempered ductile iron: Facts and Friction, Modern Casting, (1990), 3841.

[23] Daramola, O.O. Adewuyi, B.O. and Oladele, I.O.: Effect of Heat Treatment on the Mechanical properties of Rolled Medium Carbon Steel, Journal of Minerals and Materials Characterization and Engineering, vol. 8, (2010), 693-708.

[24] Kovacs, B.: The Effects of alloying Elements and their Segregation in ADI, Proceedings of International Conference on Austempered Ductile Iron, vol.1. New York, USA, (1991), 241-252.

[25] Mszka, D.: Austenite-martensite transformation in aus-tempered ductile iron, Archives of Metallurgy and Materials, vol. 52, (2007), 475-480.

[26] Liu, J.: Unique microstructure and excellent mechanical properties of $A D I, 8^{\text {th }}$ International Symposium on Science and Processing of Cast Iron, Tsinghua University, (October), vol. 3 (4), (2006), 253-257.

[27] S. Balos, S., Radisavljevic, I., Rajnovic, D., Draicanin, M., Tabakovic, S., Eric-Cekic, O. and Sidjanin, L.: Geometry, mechanical and ballistic properties of ADI material perforated plates, Materials and Design, Elevier Series, vol. 83, (2015), 66-74.

[28] Myszka, D., Olejnik, L. and Klebizyk, M.: Microstructure transformation during plastic deformation of the austempered ductile iron, Archives of Foundry Engineering, Publication of Foundry Commission of the Polish Academy of Sciences, vol. 9, (2009), 169-174.

\section{Acknowledgement}

The permission granted by the authority of the Engineering Materials Development Institute, E.M.D.I., Akure, Nigeria to carry out the experimental works of this research in their workshop is highly appreciated.

Authors: Professor A.G.F. Alabi, Ph.D., Kwara State University, College of Engineering and Technology, Department of Mechanical Engineering, Malete, Dr. J.O. Aweda, Ph.D., University of Ilorin, Faculty of Engineering and Technology, Department of Mechanical Engineering, Ilorin. Dr. F.I. Aluko, Ph.D., The Federal Polytechnic, School of Engineering, Department of Mechanical Engineering, Ado-Ekiti, Nigeria. Phone: +234 8033822017

E-mail: agfalabi@gmail.com joaweda@unilorin.edu.ng jacobaweda@gmail.com 